\title{
IAMJ
}

INTERNATIONAL

AYURVEDIC

MEDICAL JOURNAL

\section{AYURVED APPROACH TO ENDOMETRIOSIS - A CASE STUDY}

\section{Divya Pawar ${ }^{1}$, Sameer Gholap ${ }^{2}$}

${ }^{1}$ Post Graduate Scholar, ${ }^{2}$ Associate Professor and Guide; Department of Prasuti Tantra Avum Striroga, SMBT College and Hospital, Nandi Hills, Dhamangaon, Igatpuri, Nashik, Maharashtra, India

Corresponding Author: divi.pawar94@gmail.com

https://doi.org/10.46607/iamj3908082020

(Published online: August 2020)

Open Access

(C) International Ayurvedic Medical Journal, India 2020

Article Received: 26/07/2020 - Peer Reviewed: 06/08/2020 - Accepted for Publication: 06/08/2020

Check for updates

\section{ABSTRACT}

Endometriosis is the most upcoming disease that affects the quality of life of millions of women and their families worldwide. It is one of the obscure and captivating benign gynaecological disorders defined by implantation of functioning endometrial tissue outside the uterine cavity. Endometriosis is associated with a broad range of symptoms including Dysmenorrhoea, Dyspareunia, Chronic intermenstrual pelvic pain, and Infertility. The prevalence of Endometriosis in women of Reproductive age is 6-10\%. It can be compared as a syndrome complex of Paripluta Yonivyapada in Ayurveda. Thus, Vata evum Pitta shaman treatment along with regimen is given in it.

Aim and Objectives: To evaluate the efficacy of Shodhana Chikitsa as Yog Basti, Uttarbasti and Shamana Aushadhi, in the management of Endometriosis.

Materials and Methods: It is the single arm, open labelled case study of the subject of 36 yrs. age with Endometriosis who has been treated with Shodhana Chikitsa as Yog Basti, Uttarbasti and Shamana Chikitsa simultaneously. Observation and Result Chief complaints of Patient i.e. Adhodarashula (Lower abdominal pain) and Kashtartava (Pain during menstruation) were relieved. USG reports confirms and substantiates the clinical symptom free evidence.

Conclusion: The selected treatment protocol i.e. Shodhana Chikitsa as Yog Basti, Uttarbasti and Shamana Aushadhi, are found very effective in the management of Endometriosis. 
Keywords: Endometriosis, Pelvic Congestion Syndrome, Paripluta Yonivyapada, Ayurveda Etc.

\section{INTRODUCTION}

Endometriosis is most one common problem encountered in gynaecology. It affects women in their reproductive years which is associated with pelvic pain, Infertility, Dysmenorrhoea etc. Prevalence of Endometriosis is $10 \%$ but highest in infertile women about 30 $40 \%$. Its incidence appears to be increase partly due to improvements in diagnostic technique and partly due to changing social pattern like late marriages and limitation of family size. Evidence of $20 \%$ women undergoing laparoscopic investigation for infertility. Also $24 \%$ of women complains about Pelvic pain are subsequently found to have endometriosis ${ }^{[1]}$. It is the most common benign gynaecological problem which oestrogen dependent thus resolves after menopause or treatment having pseudo menopause. Paripluta yonivyapada is one of the twenty Yoni Vyapada mentioned in Ayurvedic classics. Pitta and Vata dushti states inflammation of yoni, Painful micturition, Tenderness, yellowish or bluish colour of menstrual blood, Lumbosacral and groin pain, Low backache and fever. Acharya Sushruta states that condition is said with severe Dyspareunia along with pain etc. caused by Vata Dushti. Acharya Vagbhata and Charaka states Heaviness in the region of Bladder and Lower abdomen, Di- arrhoea, Anorexia etc. In Madhukosha it is the condition of features having Vata symptoms like Pain with extreme level in periphery means Paripluta in entire internal and external reproductive organs hence termed as "Paripluta" [2]. The pelvic congestion syndrome (PCS) is a complex and multifactorial condition associated with inflammatory and hormonal etiopathogenesis similar to the endometriosis. Furthermore, both pathologies share same clinical symptoms as chronic pelvic pain and dyspareunia ${ }^{[3]}$. The presence of functioning endometrium like glands and mucosa in sites other than uterine mucosa is called as Endometriosis ${ }^{[4]}$. There are 3 most accepted theories are Sampson's Theory, This theory explains that the flow of menstrual blood gets backed up causing some of the blood to flow in reverse direction. This process causes blood containing endometrial tissue to attach to surfaces outside of the uterus. Meyer's Theory, this theory proposes that specific cells called Metaplastic cells change into endometrial cells and actually present at birth. Vascular Theory: This theory suggests that the endometrial tissue travels through the body via blood vessels. It then reaches various tissues, implants and then grows causes pain.

Table 1: Symptoms of Endometriosis ${ }^{[5]}$

\begin{tabular}{|l|l|}
\hline Site & Symptoms \\
\hline $\begin{array}{l}\text { Female reproductive } \\
\text { tract }\end{array}$ & $\begin{array}{l}\text { Dysmenorrhoea, Non menstrual pelvic pain, Dyspareunia } \\
\text { Infertility, Rupture/torsion endometrium, Low back pain }\end{array}$ \\
\hline Urinary tract & Cyclical Hematuria, Cyclical Dysuria, Ureteric obstruction \\
\hline Gastrointestinal tract & $\begin{array}{l}\text { Cyclical Dyschezia, Cyclical Rectal bleeding, Obstruction, Cyclical intestinal complaints - Pe- } \\
\text { riodic bloating, diarrhoea, constipation. }\end{array}$ \\
\hline Surgical scars/Umbilicus & $\begin{array}{l}\text { Cyclical pain and bleeding } \\
\text { Lungs }\end{array}$ \\
\hline Others & Fatigue, Cyclical Shoulder pain \\
\hline
\end{tabular}


Sites of Endometriosis

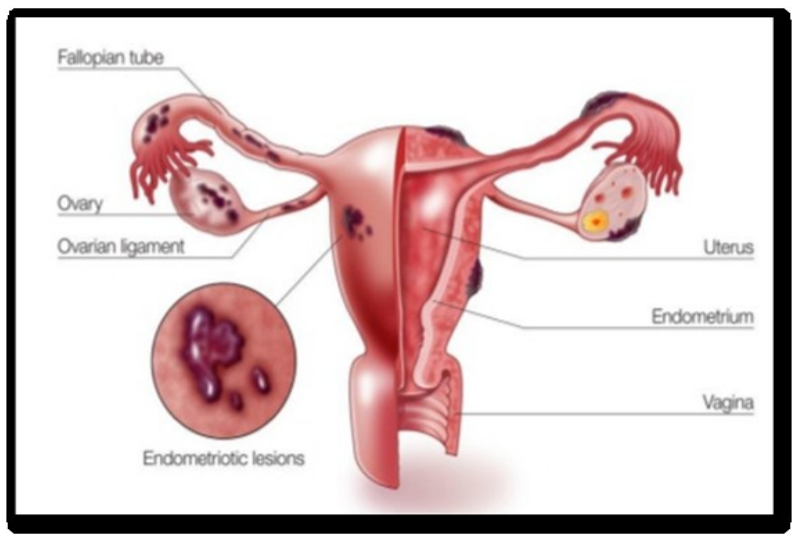

Endometriosis is reported in Ovaries, Uterine ligaments, Recto vaginal septum, Pelvic peritoneum, Laparotomy scars, Vagina, Umbilicus, Hernia sacs, Urinary tract, Large and small intestine, Appendix and rarely even in the pleura, diaphragm, arms, legs, kidneys etc. Differential Diagnosis - Endometriosis is differentially diagnosed from PID, Malignant diseases of the ovary, Myomas, malignancy of cervix and vagina etc.

\section{Paripluta Yonivyapada:}

Pittalaya Nrusavase Kshavathuudgaradharanat | Pittasamurchhito Vayuyonim Dushayari Striyaha \| Shuna Sparshakshama Sartinilapitamsruka Sravet | Shronivankshanaprushtartijwarartaya Paripluta \| (Cha.Chi.30/23)

Dosha - Vata, Pitta, Kapha, Dushya - Rasa, Rakta, Srotasa - Artavavaha srotasa, Srotodushti Vimargagamana. When who having Pitta predominance because of her Pitta Prakruti or consumption of diet which aggravates Pitta withholds her sneezing urge and eructation at the time of coitus then vitiated Pitta along with Vata reaches Yoni thus forming its abnormalities. Yoni becomes inflamed, tender and causes painful menstruation with yellowish or bluish colour of menstrual blood. Also causes Pain in Lumbosacral and groin region, backache and fever [6] Paripluta Vamini Cha Vatapittatmike Mate | (Cha.Chi.30/39) Acharya Charaka states that Paripluta, Vamini are caused by Vata and Pitta. [7]

\section{Case Reports -}

Name - Xyz

Age - 36 Yrs

Occupation - Housewife
Socioeconomic Status - Rich

Chief complaint -

Adhodarashula (Lower abdominal pain) since $2-3$ years

Kashtartava (Pain during menstruation) since $2-3$ years

Present Menstrual History (Since $\mathbf{2}-\mathbf{3}$ year) LMP - 14/05/2019, 3- 4 days / 28 - 30 days, 1 pad / day, Regular, Moderate flow, Dysmenorrhoea $(+)$, Clots $(+)$

Past Menstrual History (Before $1 \& 1 / 2$ year) 3- 4 days / 28 - 30 days, 1 pad / day, Regular, Moderate flow, No Dysmenorrhoea, No Clots

\section{Obstetric History -}

Married since 14 years

Score $=$ G1 P0 A1 D0

G1 - Female 13 years - FTND (2005)

G2 - 2 Month spontaneous abortion (2010) D \& C Done

G3 - 4 Month spontaneous abortion (2013) D \& C Done

G4 - $1 \frac{1}{2}$ Month spontaneous abortion (2014) TBPCR

- D \& C Done

G5 - Female 3 years - FTND (2015)

Past History -

No H/O of DM / HTN / BA / Hypothyroidism

No H/O of Any previous Major illness.

H/O Diagnostic Hysteroscopy with Laparoscopy + TBPCR done $3 \frac{1}{2}$ year back

$\mathrm{H} / \mathrm{O}$ Appendectomy done 18 years back.

\section{General Examination -}

Pulse - 76/min; Blood pressure - 126/82mmHg; Respiration rate $-20 / \mathrm{min}$; Height $-160 \mathrm{~cm}$; Weight -62 $\mathrm{kg} ; \quad \mathrm{BMI}-24.22$ (Normal); Temperature - 98.6; Body Build - Average; Jimha (Toungue) Ishata Sama (Slightly coated); No Pallor / Oedema / Icterus / Cyanosis / Clubbing / Lymphadenopathy; Mala - once a day;

Mutra - 10 times a day, once at night if; Shabda - Avishesha; Sparsha - Anushna Sheera; Drika - Avishesha;

Akriti - Madhyama; Prakriti - Vata Pittaja; Sara Madhyama; Vikriti - Madhyama; Bala - Madhyama; Samhanana - Madhyama; Satmya - Vyamishra; Satva 
- Madhyama; Pramana - Madhyama; Ahara ShaktiMadhyama; Jarana Shakti - Madhyama; Vyayama Shakti-Avara; Vaya-Madhyama;

Systemic Examination -

RS / CVS / CNS - Normal

Per Abdomen - Soft, Nontender, L0 S0 K0

Per Speculum -

Cervix - Parous

Normal size

No Nebothian cyst / polyp / erosion / fibroid
Vagina Healthy

No Bleeding / Discharge

Per Vagina -

Cervix - at the level of ischial spine

Uterus - Normal size

AVAF

Non mobile

Bilateral fornices - free, non-tender

No palpable adnexal mas / ovaries

Cervical motion - free, non-tender

Table 2: Investigation - (23/5/2018)

\begin{tabular}{|l|l|l|l|}
\hline $\mathrm{Hb}$ & $11.8 \mathrm{gm} / \mathrm{dl}$ & $\mathrm{T} 3$ & $91.13 \mathrm{ng} / \mathrm{dl}$ \\
\hline TLC & $9,600 / \mathrm{cumm}$ & $\mathrm{T} 4$ & $7.34 \mathrm{ng} / \mathrm{dl}$ \\
\hline RBC & $4.01 \mathrm{Mill} / \mathrm{uL}$ & HIV/VDRL/HBsAg & Non - Reactive \\
\hline ESR & $22 \mathrm{~mm} \mathrm{in} 1 \mathrm{hr}$ & PRL & 15.84 \\
\hline PLT & $2,77,000 / \mathrm{cumm}$ & LA & $31.51(\mathrm{~N})$ \\
\hline Blood group & A $+\mathrm{ve}$ & ACL & $4.2(\mathrm{~N})$ \\
\hline FBS & $98 \mathrm{mg} / \mathrm{dl}$ & Urine Pus cells, Epi cells & Nil, $1-2 / \mathrm{hpf}$ \\
\hline Sr TSH & $1.28 \mathrm{Ulu} / \mathrm{ml}$ & LFT, RFT & $\mathrm{N}$ \\
\hline
\end{tabular}

\section{USG (TAS) on 17/1/2018 [Before Treatment]}

Right renal $3 \mathrm{~mm}$ tiny calculus is seen.

Uterus - AV \& Bulky measuring 9 x 4.7 x $5.6 \mathrm{~cm}$

Endometrial thickness $-6.7 \mathrm{~mm}$ echoes are normal

Both ovaries are normal in size, shape and echotexture.

No any adnexal mass or lesion seen.

$\mathrm{RO}=3.3 \times 2.8 \mathrm{~cm}$

$\mathrm{LO}=2.7 \times 1.6 \mathrm{~cm}$

\section{USG (TAS) on 14/04/2018 [Before Treatment]}

Uterus - AV \& Bulky measuring 8.8 x 4.4 x $4.2 \mathrm{~cm}$

Endometrial thickness $-7 \mathrm{~mm}$ echoes are normal

Both ovaries are normal in size, shape and echotexture.

Collapsed post rupture follicle / cyst right.

No adnexal mass or lesion seen.

No lymphadenopathy / free fluid / dilated bowel / pleural effusion.

\section{USG (TAS) on 07/05/2019 [Before Treatment]}

Uterus is anteverted \& bulky with homogenous echotexture is seen; no focal lesion seen. Size-9.6 x 4.8 x
$5.9 \mathrm{~cm}$. ET-8 mm, echoes are normal. Multiple small Nabothian cysts are seen at the cervix. Largest $11 \times 10$ $\mathrm{mm}$ in size.

Mild tortuous, dilated uterine vessels are noticed.

Both ovaries are normal in size, shape and echotexture.

Ro size- 2.5 x 1.4 cm., Lo size- 4.2 x 3.3 cm., $(22$ x 20

$\mathrm{mm}$ follicle is seen in left ovary, another $16 \times 17 \mathrm{~mm}$ partially ruptured follicle is seen in left ovary.)

Minimal free fluid is seen in pod. No adnexal mass or lesion seen.

Conclusion: Bulky uterus with mild tortuous, dilated uterine vessels are seen possibility of Pelvic Congestion Syndrome.

\section{Treatment}

Counselling of the patient and her husband done

According to Dosha, Koshtha, Kala and Dosha Avastha, Deepana, Pachana done.

Shodhana Chikitsa

Shaman Shikitsa 
Table 3: Shodhana Aushadhi-

\begin{tabular}{|l|l|l|}
\hline Basti & Drug & Quantity \\
\hline Yog Basti $-\quad$ Sthanik Snehana With Tila Taila and Swedana With Dashamoola Kwatha \\
\hline Anuvasana Basti & Tila Taila & $120 \mathrm{ml}$ \\
\hline Niruha Basti & Erandamula Kwatha & $960 \mathrm{ml}$ \\
\hline Uttarabasti & Shatapushpa Taila & $20 \mathrm{ml}$ \\
\hline
\end{tabular}

All 3 Bastis are given on $5^{\text {th }}$ day of menstrual cycle for consecutive 3 cycles.

Table 4: Shamana Aushadhi-

\begin{tabular}{|l|l|l|l|}
\hline Drug & Dose & Duration & Anupana \\
\hline Hingwashtaka churna & $1 \mathrm{gm} \mathrm{BD}$ & Before meal & Warm Water \\
\hline Sukumara Kashaya & $15 \mathrm{gm} \mathrm{BD}$ & Before meal & 1 cup of Warm Water \\
\hline Ashokarishta & $15 \mathrm{gm} \mathrm{BD}$ & After meal & 1 cup of Warm Water \\
\hline Gandharva Haritaki & 2 tabs & Before Bed & Warm water \\
\hline
\end{tabular}

- Above treatment Shamana given for 4 months.

- Shodhana from 22/05/2019 till 22/08/2019.

- Shamana from 22/05/2019 till 27/09/2019.

Observation -

USG Report (TAS) on 28/09/2019 [After Treatment]

1) Uterus-Anteverted \& normal. No focal lesion seen.

2) Size - $8.6 \times 4.4 \times 4.3 \mathrm{~cm}$.

3) Endometrium- $6.4 \mathrm{~mm}$. Sliding sign positive -- normal.

4) Ovaries- Both are Normal.

5) No adnexal lesion seen.

6) No obvious peritoneal or bowel wall lesion of endometriosis seen.

7) No Lymphadenopathy noted / free fluid / mass lesion seen / dilated bowel / pleural effusion.

Result Chief complaints of Patient i.e. Adhodarashula (Lower abdominal pain) and Kashtartava (Pain during menstruation) were relieved. USG reports confirms and substantiates the clinical symptom free evidence.

\section{DISCUSSION}

This case study of 36-year-old lady with chief complaints of Adhodarashula (Lower abdominal pain) and Kashtartava (Pain during menstruation) since from 2 3 years. The pain slowly aggravated so she had allopathy medications which later on made Gynaecologist to suspect uterine anomaly thus advised for USG. After USG reports patient had allopathy treatment but didn't get relief. Then she came with her all reports for Ayurveda treatment. Considering all aspects like Dosha, Vaya etc. Ayurvedic treatment preferred to get treated without surgery. At the end of 3 months treatment the patient has been relieved from all her painful symptoms and has been found disease free which is confirmed in Ultrasonography reports. Aggravated Vata and thus allows the painless flow of Artava. The treatment is effective in Artava Dushti. Pelvic Congestion Syndrome is nothing but the Vata Vikara. It has similar symptoms like in Endometriosis. Thus, treatment protocol consists of Vatahara Chikitsa mainly. The possible mechanism of action of drugs are as follows,

Hingwashtaka Churna: It's All ingredient has Deepana, Pachana, Shulahara and Vatanulomaka properties thus works as Vatahara and Shulahara quality of the drug mitigates the Vata Dosha and relieves the pain. It acts like a NSAID's by direct analgesic effect by inhibition of Prostaglandins synthesis mechanism in Pelvic congestion syndrome and Endometriosis.

Sukumara Kashayam: The release of lysozymal enzymes from necrotic endometrium foster the formation of prostaglandins from cellular phospholipids via a free radical generating process which contribute to the pathology of endometriosis and pelvic congestion syndrome. It helps in alleviation of Kashtartava.

Ashokarishta: Ashokarishta is a magical tonic for the uterus. It treats dysmenorrhea (i.e. painful periods), strengthens the uterus, helps in easier removal of the uterine lining during menstruation, reducing blood 
clots during periods, hence preventing painful period cramps. The goodness of strong anti-inflammatory properties in Ashokarishta treats pelvic inflammatory disease while the powerful herbal components in Ashokarishta aid in preventing damage to the uterus, ovaries and other reproductive organs.

\section{Basti ${ }^{[8]}$ - Vatelvaneshu Dosheshu Vate Va Bastirishyate | Upakramanam Sarvesham} Sogranisrividhistu Cha \|(A.Sa.Su.19/1) Basti is a prime treatment for Vata Dosha. It has action up to Nabhi Pradesha, Kati, Prasava and Kukshi ${ }^{[9]}$. It churns the accumulated Dosha and Purisha spreads the unctuousness all over the body and easily comes out along with the churned Purisha and Dosha. It works as a Shodhana as wells brings Apana Vayu in its normal level. Basti may stimulate the enteric nervous system and thus it can influence CNS and all bodily organs. Basti may act on the neural system of body by stimulating CNS through ENS. It also acts on the inflammatory substances like prostaglandins and vasopressin etc. Basti may also help to excrete increased prostaglandins. Visceral afferent stimulation may result in activation of the Hypothalamo - pituitary adrenal axis and Autonomous nervous system, involving the release of neurotransmitters like serotonin and hormones. Thus, it normalizes the neurotransmitters, hormonal and neural pathways and relieves all the symptom complex emerged as a result of neurohormonal imbalances in Kashtartava. Spasm caused by vitiated Apana Vayu causing obstruction to the flow of menstrual blood is the general underlying pathology. Taila enters into the srotas and removes the Sankocha (spasm) by virtue of its Sookshma, Vyavayi and Vikasi i.e. fast spreading nature. Erandamula Kwatha is Kapha-Vata Shamaka and Ushna Virya. It acts as Dipana and also clears micro channels (Srotoshodhana). It is mentioned as best Vatahara (Vata pacifying). So, by virtue of all these property Erandamula Kwatha acts very efficiently in disease of Vata. So, considering all the above properties of each drug, preparations used work very effectively as a whole in the Vata disease. Tila Taila according to Acharya Sushruta ${ }^{[10]}$ has considered Tila Taila as Yonishula Prashamana \& Garbhashaya Shodhana. It is Sara, Vyavayi, Vikasi, Krimighna \& Vranaghna. All these Guna make it a suitable medium, as it may itself act to painful periods. Probably it clears pathogenesis of dysmenorrhoea.

\section{Uttarabasti -}

Intrauterine Uttarabasti facilitates the absorption of drug in uterus. It helps in rejuvenation of endometrium. Uterus is the Mulasthan of Artava Vaha Srotasa. The drug being directly instilled in the uterus gives direct access to the seat of Strotovaigunya and Dosha Dushya-Sammurchana and hence acts on the Vikrut Vayu thereby disintegrating the Samprapti. It may be also possible the drug given by the intra-uterine route may stimulate the certain receptors in the endometrium leading to correlation of all the physiological processes of reproductive system. Tikta Rasa of Shatapushpa causes rasraktashodhana, Agnideepana and Amapachan. Katurasa of it helps in Rutupravartan, Yonishukravishodhana. Ushna Virya of Shatapushapa works as Vatashamaka. Madhura Rasa of Shatapushapa acts as Sthanik Balya and Pittashamana. Shatapushpa has a phytoestrogen, it exerts both estrogenic and anti-estrogenic activity. It acts in both high oestrogenic and low oestrogenic condition. Thus, it brings the normal endometrial thickness.

\section{CONCLUSION}

The management of Pelvic Congestion Syndrome and related sub infertility is typically with surgery which has a modest effect and surgical excision of endometriosis improves spontaneous infertility and sometimes associated with normal ovarian tissue removal decreasing the ovarian reserve. The surgical and medical management of chronic pelvic pain associated with endometriosis are effective but with high recurrence rates incurring severe financial burden. Thus, its timely management prevents upcoming Infertility thus bringing favourable outcome. Treatment must be individualized and taken into consideration the impact of the condition on the quality of life. Above Ayurvedic treatment gave relief by relieving congested pain in lower abdomen and its pathology. 


\section{REFERENCES}

1. Practical Cases in OBSTETRICS AND GYNECOLOGY. $37^{\text {th }}$ chapter endometriosis. In: Kanan yelikar. Textbook of Gynaecology and Obstetrics, $1^{\text {st }}$ ed. New Delhi: Jaypee Publications; 2007:252.

2. Premavati Tewari, Ayurvedia Prasuti tantra evum strirog part-II striroga, 2007, p.31,109.

3. https://clinicaltrials.gov/ct2/show/NCT03568149\#con$\underline{\text { tacts }}$

4. D C Dutta. $21^{\text {th }}$ chapter Endometriosis. In: Hiralal Konar. Textbook of Gynaecology, $6^{\text {th }}$ ed. New Delhi: Jaypee Publications; Enlarged and revised, Reprint Nov 2013:304.

5. Gynaecology by Ten teachers. $11^{\text {th }}$ chapter Endometriosis. Edited By Ash Monga \& Stephen Dobbs Textbook of Gynaecology, 19 ${ }^{\text {th }}$ ed. Hoder Arnold 2011:104.

6. Agnivesa, Dridhabala, Charak Samhita, Chikitsa Sthana, Yonivyapada chikitsaadhyaya, 30/23, edited by
Acharya PriyaVata Sharma, Chaukhamba Orientalia, Varanasi, 1998:504

7. Agnivesa, Dridhabala, Charak Samhita, Chikitsa Sthana, Yonivyapada chikitsaadhyaya, 30/39, edited by Acharya PriyaVata Sharma, Chaukhamba Orientalia, Varanasi, 1998:506

8. Charak Samhita of Agnivesha, revised by Charaka and Drdhabala, with introduction by Vaidya-Samrata Sri Satya Narayana Shastri with elaborated Vidyotini Hindi commentary by Pt. Kasinatha Shastri \& Dr. Gorakha natha chaturvedi, editorial board Pt. Rajeswaradatta Shastri, Part-2, Chaukhamba Bharti Academy Varanasi,Reprint-2009, Siddhi Sthana 1/40, page no.971,972

9. Dr.Radha Agrawal, Arya Vaidyasala, Kottakkal-Basti concept and current procedural modalities. page no.136.

10. Dr. Ambikadatta Shastri, Sushruta Samhita, AyurvedaTattva-Samdipika commentary, Su. 45/112, Chaukhamba Sankrit Pratishthana, Varanasi, 2003.

\section{Reports -}

\section{1) Before Treatment}

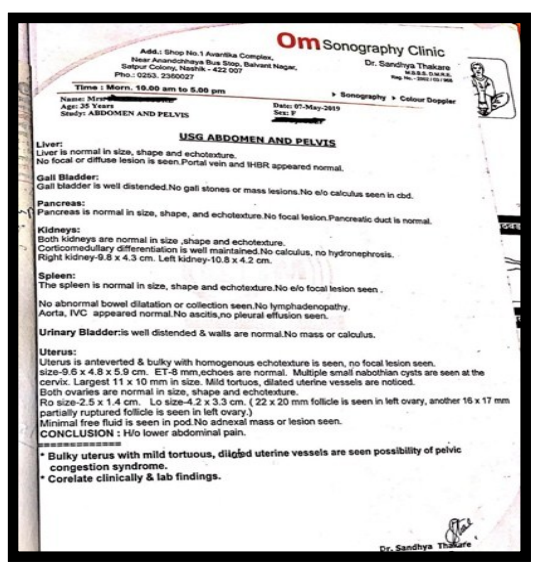

(A)

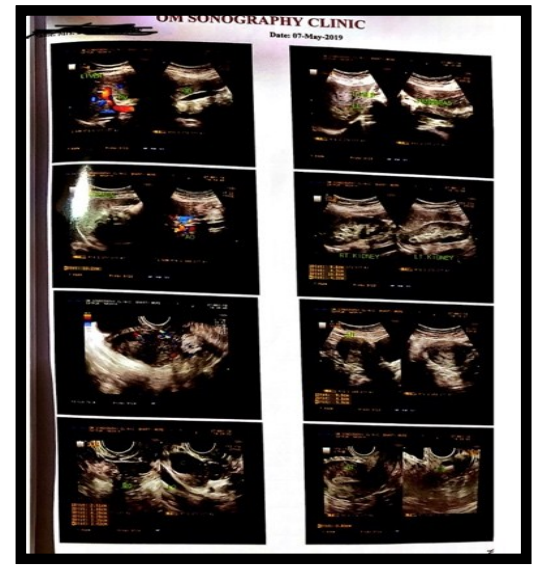

(B)

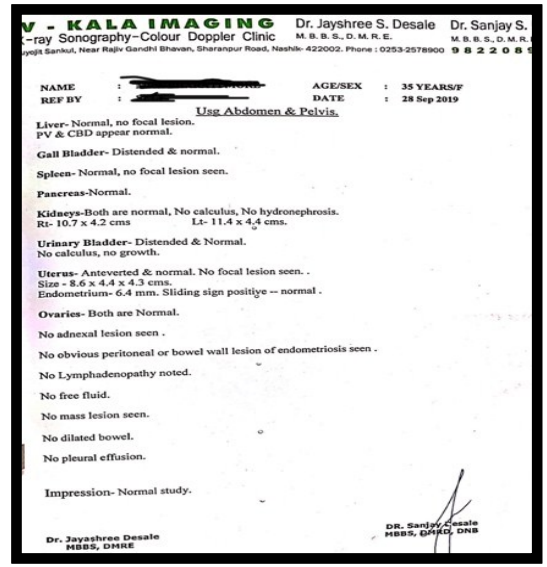

After Treatment

\section{Source of Support: Nil Conflict of Interest: None Declared}

How to cite this URL: Divya Pawar \& Sameer Gholap: Ayurved Approach To Endometriosis - Case Study. International Ayurvedic Medical Journal \{online\} 2020 \{cited August, 2020\} Available from: http://www.iamj.in/posts/images/upload/4271_4277.pdf 